\title{
Effects of Land Use on Greenhouse Gas Flux in Playa Wetlands and Associated Watersheds in the High Plains, USA
}

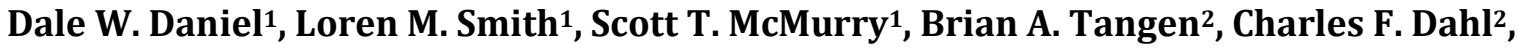 \\ Ned H. Euliss Jr. ${ }^{2}$, Ted LaGrange ${ }^{3}$ \\ ${ }^{1}$ Department of Integrative Biology, Oklahoma State University, Stillwater, OK, USA \\ ${ }^{2}$ U.S. Geological Survey, Northern Prairie Wildlife Research Center, Jamestown, ND, USA \\ ${ }^{3}$ Nebraska Game \& Parks Commission, Wetlands Program, Lincoln, NE, USA \\ Email: dale.daniel@okstate.edu
}

How to cite this paper: Daniel, D.W., Smith, L.M., McMurry, S.T., Tangen, B.A., Dahl, C.F., Euliss Jr., N.H. and LaGrange, T. (2019) Effects of Land Use on Greenhouse Gas Flux in Playa Wetlands and Associated Watersheds in the High Plains, USA. Agricultural Sciences, 10, 181-201. https://doi.org/10.4236/as.2019.102016

Received: September 24, 2018

Accepted: February 24, 2019

Published: February 27, 2019

Copyright $\odot 2019$ by author(s) and Scientific Research Publishing Inc. This work is licensed under the Creative Commons Attribution International License (CC BY 4.0).

http://creativecommons.org/licenses/by/4.0/

\begin{abstract}
In the High Plains, U.S., native prairie conversion to cropland agriculture has resulted in a loss of service delivery capabilities from most depressional wetlands as a result of sedimentation. Restoring historic hydrological conditions to affected wetlands may rejuvenate some services, however, there may be tradeoffs due to emissions of $\mathrm{CH}_{4}$ and $\mathrm{N}_{2} \mathrm{O}$. We evaluated the influence of two predominant conservation programs (Wetlands Reserve Program, WRP and Conservation Reserve Program, CRP) on gas emissions $\left(\mathrm{CO}_{2}, \mathrm{CH}_{4}, \mathrm{~N}_{2} \mathrm{O}\right)$ from 42 playas and uplands in the High Plains of Nebraska. Because playa restoration through the WRP is most prevalent in the Rainwater Basin (RWB), we studied 27 playas/uplands among reference condition, cropland, and WRP land uses. We studied 15 playas/uplands within native grassland, cropland, and CRP land uses in the Western High Plains (WHP) of Nebraska. Emissions were collected bi-weekly from April-October of 2012 and 2013 from four landscape positions extending outward from the wetland center into upland. In RWB playas, $\mathrm{CH}_{4}$ and $\mathrm{N}_{2} \mathrm{O}$ emissions were similar among land uses but $\mathrm{CO}_{2}$ was $28 \%$ higher in cropland than WRP wetlands. Cropland uplands emitted $648 \%$ more $\mathrm{N}_{2} \mathrm{O}$ than reference and WRP uplands. Overall, net $\mathrm{CO}_{2 \text {-equiv }}$ emissions were lower in playas/uplands in WRP, suggesting that benefits of playa restoration may include climate mitigation services as well as increased water storage capacity and biodiversity provisioning. In the WHP, cropland and grassland playas emitted 46 and 23 times more $\mathrm{CH}_{4}$, respectively, than CRP in 2013. Playas in CRP emitted $43 \%$ less $\mathrm{N}_{2} \mathrm{O}$ than cropland playas. In 2013, net emissions for cropland and native grassland playas were $75 \%$ and 39\% greater, respectively, than CRP playas. In the WHP, the benefits
\end{abstract}


of lower gas emissions must be appropriately weighted against tradeoffs of ecosystem services related to shorter hydroperiods as a result of reduced runoff into playas in CRP.

\section{Keywords}

Conservation Reserve Program, Depressional Wetlands, Ecosystem Services, Global Climate Change, Wetlands Reserve Program, Wetland Restoration

\section{Introduction}

Land use change has been identified as the most significant human impact to global climate [1]. Converting land from natural vegetative conditions changes the physical properties of the landscape including surface heat fluxes and albedo [1], which consequently alters biogeochemical functioning [2] [3]. When soils are disturbed, stored carbon molecules become exposed to microbial activity which releases soil bound carbon into the atmosphere [4]. Natural ecosystems that are converted to cropland can have up to $50 \%-70 \%$ carbon loss from soils [5]. Estimates suggest that land conversion is responsible for approximately $25 \%$ of net anthropogenic greenhouse gas (GHG) emissions [2].

Watershed alterations and conversion of wetland ecosystems to other uses can have a substantial impact on climate [6]. Wetland systems are among the most productive ecosystems in the world and have a large capacity to sequester atmospheric carbon [7]. It is estimated that $771 \mathrm{GtC}$ is still contained within wetland systems, an amount comparable to the carbon concentration of today's atmosphere [8]. By the 1980s, more than half of U.S. wetlands had been lost to agricultural enterprise and those that were not lost were subject to degradation including nutrient and chemical runoff, sediment erosion, and physical alteration [9] [10]. Wetland loss due to land conversion has resulted in net emissions of carbon into the atmosphere [11] [12].

By protecting degraded wetlands from further land conversion and restoring hydrology, wetland functional attributes including carbon sequestration may be restored [13] [14]. However, there is debate as to the influence wetland restoration has on climate mitigation potential. [6] suggested that the carbon sink of North American wetlands is counterbalanced by their $\mathrm{CH}_{4}$ emissions and wetland conversion to other land uses has resulted in a reduction in net radiative forcing in North America. It is often assumed that by restoring wetlands, any increases in carbon sequestration will be offset by subsequent increases in $\mathrm{CH}_{4}$ [6] [15]. Nitrous-oxide emissions may also be increased in wetland restoration sites that were previously fertilized croplands [16].

Land conversion for cultivation constitutes the most significant land use change in the U.S. and agriculture was responsible for $9 \%$ of total GHG emissions in 2012 [17]. The U.S. Great Plains is among the most heavily cultivated regions in the world and is likely to be a fundamental contributor to present and 
future climate change [18]. However, little is known about the flux strength of the numerous depressional playa wetlands that occupy the High Plains portion of the Great Plains.

Playa wetlands exist as the dominant surface water feature on the High Plains landscape and their natural functioning provides critical ecosystem services that are not provided elsewhere [19]. Cropland agriculture is the major threat to playa hydrology and concomitant functioning, with impacts from physical modifications to sediment accumulation [20] [21]. [22] estimated that $60 \%$ of playa wetlands in the Southern High Plains have been physically lost due to sediment filling and $95.3 \%$ of playas have been modified. Increased sediment loads in playas force water to spread over a larger area, thus increasing evaporation loss and water infiltration into porous upland soils [23]. [24] found that water loss rates were higher in playas with highly cultivated upland watersheds compared to native grasslands. Decreased ponding times of playas favor the establishment of more xeric flora that are often less productive than wetland species [25]. Impacts from native grassland conversion to cropland result in diminished playa service capacity [19] and ultimately change the basic biogeochemical drivers mediating influxes and effluxes of GHGs.

In the High Plains, there are conservation programs and incentives available for landowners that provide playas protection from negative agricultural effects [19]. Some programs such as the U.S. Department of Agriculture's (USDA) Wetlands Reserve Program (WRP) are designed to restore wetland functioning by implementing practices including sediment removal and wetland buffer establishment. The largest conservation program in the U.S. is the USDA's Conservation Reserve Program (CRP) which is designed to conserve highly erodible cropland and did not, historically, consider wetlands [19]. The CRP primarily affects wetlands by influencing runoff from their watersheds [26]. Runoff is the largest water contributor to the playa water budget [21]. Because these programs implement differing conservation practices, they may have different contributions to GHG fluxes based upon their influence on playa hydrology.

As one of the largest contributors to global atmospheric GHGs, the United States has taken steps to reduce its emissions [27]. With a better understanding of not only regional emissions contributions but the contributions from ecosystem interactions within those regions, we can provide better insight into possible mitigation strategies. Though playas only occupy $2 \%-5 \%$ of the Great Plains landscape [28], they may be of critical importance to the GHG budget. Their capacity to provide climate mitigation services, however, may be threatened by cropland agriculture. Conservation programs are highly concentrated in the Great Plains but none of these programs implement practices specifically for reducing GHG emissions. These conservation programs have significant influences on playa hydrology and therefore on the relative contribution of playas to GHG emissions. This study evaluated the effects of differing land use types and conservation programs (WRP and CRP) on GHG emissions in playa wetlands and adjacent uplands. 


\section{Study Area}

Playas were sampled from the western High Plains (WHP) and Rainwater Basin (RWB) regions of Nebraska [29]. Playas in the WHP occupy all or part of 13 counties in the southwest corner of Nebraska, south of the Platte River [29]. They coincide with the short-grass prairie ecoregion which receives low annual rainfall of $40-45 \mathrm{~cm} \cdot \mathrm{yr}^{-1}$ and high annual evapotranspiration of about 165 $\mathrm{cm} \cdot \mathrm{yr}^{-1}$ [21]. The region is characterized by nearly flat loess soils with the predominant hydric soil being the Lodgepole series [30]. On average, playas in this region are less than 4 ha in size [31]. Croplands typically consist of wheat, corn, and soybeans [30] and playas in this region often dry up early in the year and are planted through [29]. The most common conservation program implemented in this region is the CRP which occupies more than 131,000 ha of that landscape [30].

The RWB is characterized by gently rolling loess plains historically dominated by mixed-grass and tall-grass prairie [32]. Annual precipitation is greater in the RWB than in WHP playas, receiving on average, $69 \mathrm{~cm} \cdot \mathrm{yr}^{-1}$ [33]. Hydric soils consist of Fillmore, Scott, and Massie series that differ in their properties based upon their length of inundation and in many cases all three soils may exist within a single playa basin [34]. Playas in this region range from 0.1 to 1000 ha in size and from 1 to $5 \mathrm{~m}$ in depth [35] giving them the potential to store large quantities of surface water; however, most of the smaller wetlands have been lost [21] [35] [36]. Estimates of historic wetland numbers in the RWB suggest that approximately 4000 wetlands covering 38,000 ha originally existed, however, agricultural practices in the region have resulted in the functional loss of many of these playas from and by 1983 only $10 \%$ of the wetlands and $22 \%$ of the area remained [36]. As an area identified by the U.S Fish and Wildlife Service as one of the nine areas of critical concern for wetland loss, conservation programs specifically designed for wetland restoration are of critical importance to the RWB. Thus, over 2600 ha of playa wetlands in this region have been restored by WRP easements (N. Walker pers. comm., 2015).

\section{Methods}

GHG emissions were monitored on 42 wetlands in the High Plains; 27 wetlands in the RWB and 15 wetlands in the WHP region. Wetlands included in the RWB were evenly split among reference, WRP restored, and cropland watersheds and the WHP playas were split among native grassland, CRP, and cropland watersheds. Wetland sites were selected at random from RWB Joint Venture (RWBJV) GIS layers (www.rwbjv.org). For the purpose of this study, reference wetlands represent reference standard sites that are determined to be the least altered and most closely resemble historic levels of functioning [32]. Reference playas in the RWB were selected from a list of playas that had been classified as such by Nebraska Games and Parks Commission (NGPC) personnel. Their suitability as reference playas was based on four criteria: 1) very negligible to no 
hydrologic modifications, 2) a natural vegetative community with little to no invasive or problematic species of plants, 3) a watershed that is unaffected by physical alterations that would prevent runoff from reaching the basin, and 4) the correct water regime for the hydric soils present.

GHG emissions from each wetland were sampled between 10:00 and 14:00 every two weeks from April 1-October 31 during 2012 and 2013. Samples were collected using the static chamber method [37] following the methods of [38] and [39]. Collection chambers consisted of a polyvinyl chloride chamber lid (20 $\mathrm{cm}$ diameter, $20 \mathrm{~cm}$ height, $314.16 \mathrm{~cm}^{2}$ ) with a pressure vent and septa for syringe sampling. Chamber lids were sealed to chamber bases that were secured to the soil surface. Each base was situated $5 \mathrm{~cm}$ into the soil for the duration of the study. When water levels were $>5 \mathrm{~cm}$, chamber lids were attached to floating bases and positioned above the original base on the water surface. Any vegetation within chamber bases remained throughout the duration of the study and chambers with vegetation that exceeded the height of the chamber lid were fitted with chamber extensions. To account for variations in emissions across environmental gradients, a static chamber was established and sampled from at four separate landscape positions at each wetland/upland site; 1) wetland center, 2) mid-distance between wetland center and wetland edge, 3) wetland edge, and 4) upland slope [38].

A gas volume of $50 \mathrm{~mL}$ was drawn from each collection chamber after a 30-minute accumulation period determined to be sufficient based on previous studies [38] [39] [40]. The collected gas was transferred and stored over-pressurized in $10 \mathrm{ml}$ pre-evacuated $(<10$ torr) crimp top serum bottles fitted with gas-impermeable septa.

Gases were analyzed within one week of collection using a SRI Model 8610 gas chromatograph (SRI Instruments, Torrance, CA, USA) equipped with electron capture (ECD) and flame-ionization (FID) detectors and two 10-port valves to measure $\mathrm{N}_{2} \mathrm{O}, \mathrm{CH}_{4}$, and $\mathrm{CO}_{2}$ with a single injection of sample [38]. The instrument configuration and operating conditions (modified from [41]) provided


ppmv $\mathrm{CO}_{2}$ (FID). Emissions values $\left(\mathrm{g} \cdot \mathrm{ha}^{-1} \cdot \mathrm{day}^{-1}\right.$ ) for $\mathrm{CO}_{2}$ and $\mathrm{N}_{2} \mathrm{O}$ and flux values for $\mathrm{CH}_{4}$ and were calculated for each collection chamber on each sample date using methods described by [42]. Two ambient air samples were also collected at each wetland location during each sampling event and analyzed along with the emissions samples to provide baseline measurements. The average ambient air concentrations were subtracted from the emissions sample concentrations to determine actual emission concentration. To determine the impact of differing land use types on net radiative forcing, $\mathrm{N}_{2} \mathrm{O}$ and $\mathrm{CH}_{4}$ emissions were standardized into $\mathrm{CO}_{2}$ equivalents using the Global Warming Potential (GWP) metric over a 100-year time horizon $\left(\mathrm{N}_{2} \mathrm{O}=296, \mathrm{CH}_{4}=23\right.$; [43]).

Rates of GHG emissions from wetlands depend on multiple interacting factors including land use practice, temperature, water level, and plant properties that influence quantity and quality of organic matter [44] [45]. To better understand 
the underlying differences in processes driving GHG fluxes in playas and uplands among land use types, we also collected soil moisture, soil temperature, aboveground plant biomass, and plant species richness data at each site. Soil temperature and volumetric water content were measured at each chamber base location during every sampling event using a thermometer and Field Scout 300 TDR soil moisture meter (Spectrum Technologies, Aurora, IL, USA). To determine potential influence of plant communities within and among land use types, we used step-point surveys to estimate plant cover [46] in playas and watersheds during the 2013 sampling season. Transects extended from wetland edge to wetland edge and $100 \mathrm{~m}$ into the upland on both sides. Plant surveys were conducted in May and in August to account for cool to warm plant species turnover [25]. At peak growing season (June-July), aboveground biomass was collected from a $50 \mathrm{~cm} \times 50 \mathrm{~cm}$ quadrat [47] at each landscape position corresponding to each chamber base location. Quadrats were clipped away from the chamber base as to not affect future sampling events. Clipped biomass was dried at $65^{\circ} \mathrm{C}$ until a constant weight was achieved [47].

\section{Statistical Analyses}

A general linear mixed model (PROC GLIMMIX; SAS 9.4) was used to assess the factors important in influencing GHG emissions $\left(\mathrm{CO}_{2}, \mathrm{CH}_{4}, \mathrm{~N}_{2} \mathrm{O}\right.$, and net $\mathrm{CO}_{2 \text {-equiv }}$ emissions) from playa wetlands and adjacent uplands in the RWB and WHP. Fixed effects included land use type (reference, cropland, WRP in the RWB; native grassland, cropland, CRP in the WHP), landscape position (wetland edge, wetland center, half the distance between edge/center), sampling period, year, land use type * landscape position interaction, and land use type * year interaction for playa wetlands $(\alpha=0.1)$. For adjacent uplands, landscape position fixed effects were not included because uplands were only sampled at a single point. Repeated measures were taken on each experimental unit (individual sampling points at each wetland/adjacent upland site) resulting in a maximum of 28 observations (bi-weekly sampling periods) within 108 subjects in the RWB and 60 subjects in the WHP. A Gaussian distribution model (identity link function) was selected and restricted maximum likelihood approximations were used to estimate model parameters. Residual denominator degrees of freedom were used and fixed effect standard errors were adjusted using a sandwich estimator. Tukey-Kramer multiple comparison tests on adjusted least square means were performed to determine differences among fixed effect means. Margins for least square means were adjusted to be proportional to the observed margins within each level of fixed effects.

Soil moisture and soil temperature were also analyzed as dependent variables to determine differences across fixed effects using the same model as described above. Aboveground plant biomass and plant species richness were not included in these analyses because data were only collected during the 2013 sampling season and did not include repeat measures on experimental units. 
Separate one-way analyses of variance (PROC GLM; SAS 9.4) were used to assess the effects of land use on plant species richness and aboveground biomass in playas/uplands in the RWB and WHP in 2013. A protected Duncan's multiple range test was used to assess specific treatment differences $(\alpha=0.05)$.

Due to site selection constraints, some cropland playas in the RWB were clustered at two locations. In order to remove potential sample bias related to proximity, models were analyzed a second time with one playa removed from each clustered location. Raw data were examined for outlying gas values orders of magnitude above other measurements within a sampling period. Each gas value was examined along with corresponding site specific field data to determine validity of the measurement. Rather than removing an entire sample site from the data, gas specific extreme values that could not be explained by corresponding field data were removed individually, thus leaving the remaining gas species for analysis. A total of $6 \mathrm{CO}_{2}$ and $5 \mathrm{CH}_{4}$ extreme values could not be explained by corresponding field data and were removed from wetland measurements $\left(\mathrm{RWB}=1 \mathrm{CO}_{2}, \mathrm{WHP}=5 \mathrm{CO}_{2}\right.$ and $\left.5 \mathrm{CH}_{4}\right)$ and $10 \mathrm{CH}_{4}$ extreme values were removed from upland measurements $\left(\mathrm{RWB}=5 \mathrm{CH}_{4}, \mathrm{WHP}=5 \mathrm{CH}_{4}\right)$.

\section{Results}

All statistical analyses result tables as well as seasonal net $\mathrm{C}$ emissions figures are provided in supporting information section.

\subsection{Rainwater Basin Wetlands}

Removing the two clustered cropland playas from the analyses did not influence statistical significance at $\alpha=0.1$, therefore results are presented for the model including all sample sites in the RWB.

There were no interactions among fixed effects for any GHG emissions in RWB playas. There was seasonal variation in all GHG emissions with the bulk of emissions occurring during peak growing season. Emissions of $\mathrm{CO}_{2}$ differed among land use types but not by landscape position or by year. Cropland playas emitted $28 \%$ more $\mathrm{CO}_{2}$ than WRP playas; reference playas did not differ from either cropland or WRP playas (Table 1). Methane fluxes differed among landscape positions but did not differ by land use type or by year. As expected, $\mathrm{CH}_{4}$ emissions were highest in the wetland center and decreased at each landscape position moving outward to the wetland edge (Table 2). Emissions of $\mathrm{N}_{2} \mathrm{O}$ did not differ among land use types, landscape positions or by year. Net emissions differed among land use types and landscape positions but not by year. Cropland playas emitted $53 \%$ more $\mathrm{CO}_{2 \text {-equiv }}$ than WRP playas; reference playas did not differ from either cropland or WRP playas (Figure 1(a)). The bulk of emissions occurred at the center of the wetland which differed from both the wetland edge and $1 / 2$ distance between center and edge, which did not differ from one another.

There were no interactions among fixed effects for soil moisture and soil temperature in RWB playas. Seasonal variation existed for soil moisture which 
Table 1. Mean $( \pm \mathrm{SE})$ for $\mathrm{CO}_{2}$-equiv $\mathrm{C}$ emissions $\left(\mathrm{g} \cdot \mathrm{ha}^{-1} \cdot \mathrm{day}^{-1}\right)$ of greenhouse gases in rainwater basin and western high plains playas and uplands. data are pooled by land use type.

\begin{tabular}{|c|c|c|c|c|c|c|}
\hline & \multicolumn{6}{|c|}{ Rainwater Basin } \\
\hline & \multicolumn{3}{|c|}{2012} & \multicolumn{3}{|c|}{2013} \\
\hline & $\mathrm{CO}_{2}-\mathrm{C}$ & $\mathrm{CH}_{4}-\mathrm{C}$ & $\mathrm{N}_{2} \mathrm{O}-\mathrm{C}$ & $\mathrm{CO}_{2}-\mathrm{C}$ & $\mathrm{CH}_{4}-\mathrm{C}$ & $\mathrm{N}_{2} \mathrm{O}-\mathrm{C}$ \\
\hline \multicolumn{7}{|l|}{ Playa } \\
\hline Cropland & $45,031(3019)$ & 32,738 (7992) & $1062(241)$ & $44,266(2671)$ & 23,986 (9309) & $1385(423)$ \\
\hline Reference & $41,272(4105)$ & $34,231(13,141)$ & $1313(388)$ & $36,974(2402)$ & $24,960(8066)$ & $1285(347)$ \\
\hline WRP & $36,284(4302)$ & $17,107(10,885)$ & $1006(393)$ & $33,774(2880)$ & 7664 (2722) & $1365(509)$ \\
\hline \multicolumn{7}{|l|}{ Upland } \\
\hline Cropland & $43,958(5879)$ & $58.6(40.1)$ & $3652(1109)$ & $45,212(6040)$ & $254.0(187)$ & $6796(1910)$ \\
\hline Reference & $42,885(5314)$ & $21.4(14.7)$ & $228(140.9)$ & $46,010(6871)$ & $1611.8(1452.8)$ & $1166(572)$ \\
\hline \multirow[t]{2}{*}{ WRP } & $42,138(4527)$ & $-2.6(11.4)$ & $421(81.4)$ & $45,739(4506)$ & $21.7(17.6)$ & $985(660.9)$ \\
\hline & \multicolumn{6}{|c|}{ Western High Plains } \\
\hline \multicolumn{7}{|l|}{ Playa } \\
\hline Cropland & $26,366(1897)$ & $-4.2(1003.0)$ & $327(71)$ & $28,470(2912)$ & $14,172.0(5015.0)$ & $572(150)$ \\
\hline Grassland & 24,377 (1994) & $1641.2(942.3)$ & $1019(445)$ & $27,010(3389)$ & $7053.0(3388.3)$ & $411(94)$ \\
\hline CRP & $34,561(4004)$ & $-8.5(49.0)$ & $205(27)$ & $24,374(2535)$ & $288.3(285.2)$ & $315(61)$ \\
\hline \multicolumn{7}{|l|}{ Upland } \\
\hline Cropland & $24,119(2957)$ & $1.6(8.5)$ & $202(33)$ & $27,093(4453)$ & $4.1(12.6)$ & $407(240)$ \\
\hline Grassland & $27,578(3082)$ & $-5.3(2.8)$ & $165(69)$ & $37,954(3407)$ & $-49.6(6.4)$ & $437(153)$ \\
\hline CRP & $28,470(4862)$ & $-21.5(10.0)$ & $182(75)$ & $30,582(1154)$ & $-4.7(8.2)$ & $190(61)$ \\
\hline
\end{tabular}

Table 2. Mean $( \pm \mathrm{SE})$ for $\mathrm{CO}_{2}$-equiv C emissions $\left(\mathrm{g} \cdot \mathrm{ha}^{-1} \cdot \mathrm{day}^{-1}\right)$ of greenhouse gases in Rainwater Basin and Western High Plains playas and uplands. Data are pooled by landscape position (1) wetland center, (2) between wetland center/wetland edge, (3) wetland edge, (4) upland.

\begin{tabular}{cccc}
\hline & \multicolumn{3}{c}{ Rainwater Basin } \\
\cline { 2 - 4 } & $\mathrm{CO}_{2}-\mathrm{C}$ & $\mathrm{CH}_{4}-\mathrm{C}$ & $\mathrm{N}_{2} \mathrm{O}-\mathrm{C}$ \\
\hline Landscape Position & & & $1583(371)$ \\
1 & $40,127(2271)$ & $49,072(10,878)$ & $1030(265)$ \\
2 & $36,760(2770)$ & $17,861(4394)$ & $1097(313)$ \\
3 & $41,952(2121)$ & $3377(1393)$ & $2210(537)$ \\
4 & $44,323(3223)$ & $328(252)$ & $510(94)$ \\
2 & & $6140(2151)$ & $561(198)$ \\
4 & $24,849(1960)$ & $4958(2298)$ & $367(50)$ \\
\end{tabular}




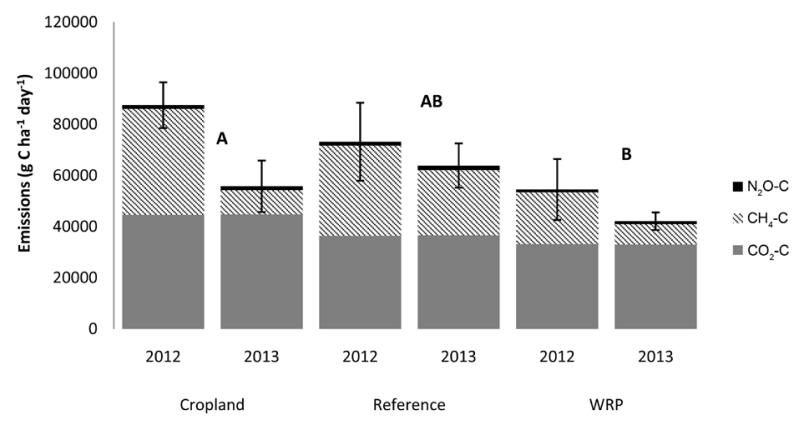

(a)

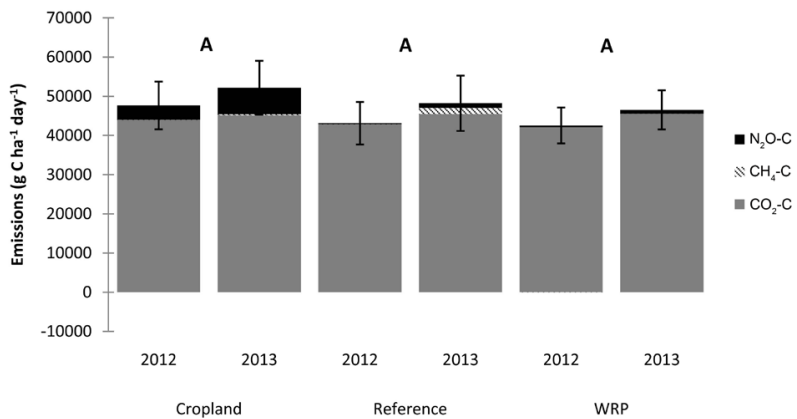

(b)

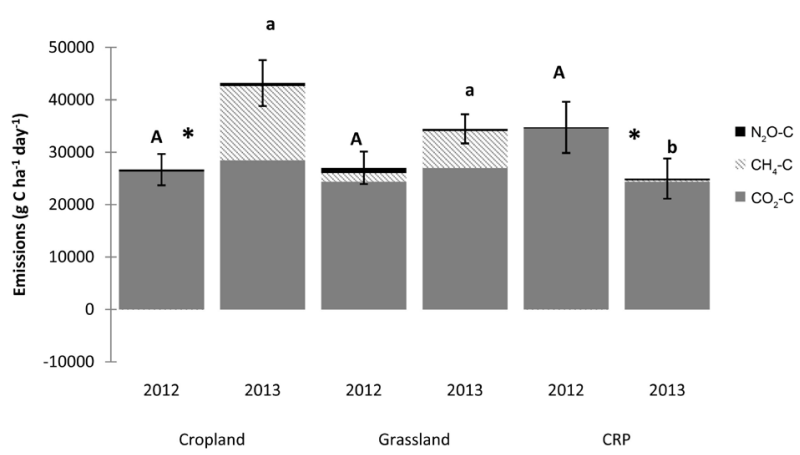

(c)

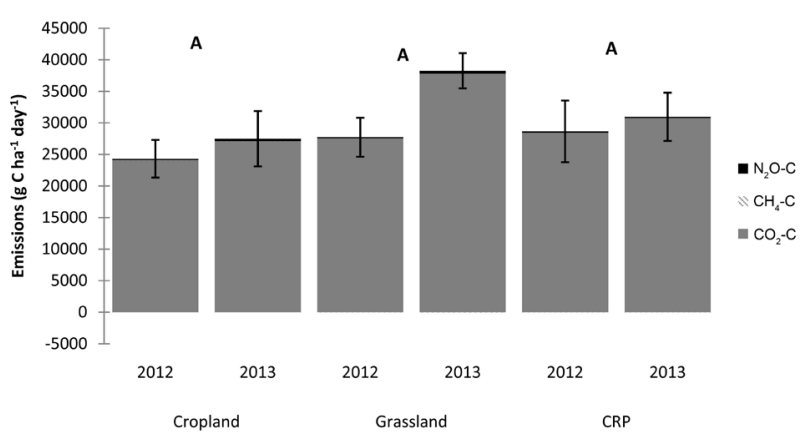

(d)

Figure 1. Mean ( \pm SE) net C emissions in 2012 and 2013 for (a) Rainwater Basin (RWB) playas; (b) RWB uplands; (c) Western High Plains (WHP) playas; and (d) WHP uplands. Capital letters alone indicate differences among land use types without a year interaction. When both capital and lower-case letters are visible, capital letters represent differences among land use types for 2012 and lower-case letters designate differences among land use types for 2013. Asterisks indicate differences between years within a single land use type. 
was generally highest early in the season, coinciding with snow melt and spring rains. Soil moisture also differed among land use types, landscape positions, and by year. Playas in WRP had 19\% lower soil moisture than cropland and reference playas, which did not differ (Table 3). Soil moisture was also lower at the wetland edge than at either point in the wetland basin; wetland basin landscape positions (positions 1 and 2) did not differ from one another. Finally, there was an $8 \%$ increase in soil moisture in 2013 compared to 2012. There was seasonal variation in soil temperature which was obviously highest during summer. Soil temperature also differed among land use types and by year but not among landscape positions. Playas in the WRP were approximately $1.4^{\circ} \mathrm{C}$ warmer than reference and cropland playas, which did not differ from one another (Table 3 ). Also, playa soils were approximately $1.6^{\circ} \mathrm{C}$ warmer in 2012 than in 2013.

Plant species richness did not differ among land uses in playas in 2013, however aboveground biomass did. Cropland playas had 30\% more aboveground biomass than reference condition playas and 63\% more than playas in WRP; reference condition playas had 35\% more aboveground biomass than playas in WRP (Table 3).

Table 3. Mean ( \pm SE) soil moisture and soil temperature (April through October), aboveground plant biomass (single measurement), and plant species richness (early and late season) in Rainwater Basin and Western High Plains playas and uplands.

\begin{tabular}{|c|c|c|c|c|}
\hline & \multicolumn{4}{|c|}{ Rainwater Basin } \\
\hline & Moisture (\%VWC) & Temperature $\left({ }^{\circ} \mathrm{C}\right)$ & Biomass $\left(\mathrm{g} / \mathrm{m}^{2}\right)$ & Richness \\
\hline \multicolumn{5}{|l|}{ Playa } \\
\hline Cropland & $47.5(2.0)$ & $17.2(0.1)$ & $835(66)$ & $14(2.2)$ \\
\hline Reference & $49.5(2.4)$ & $17.7(0.2)$ & $617(45)$ & $20(2.5)$ \\
\hline WRP & $40.3(1.7)$ & $18.9(0.2)$ & $431(40)$ & $19(1.9)$ \\
\hline \multicolumn{5}{|l|}{ Upland } \\
\hline Cropland & $31.0(2.4)$ & $18.2(0.3)$ & $513(77)$ & $8(0.7)$ \\
\hline Reference & $26.1(1.4)$ & $18.2(0.3)$ & $601(73)$ & $14(1.4)$ \\
\hline \multirow[t]{2}{*}{ WRP } & $23.2(1.4)$ & $19.1(0.2)$ & $583(76)$ & $12(1.5)$ \\
\hline & \multicolumn{4}{|c|}{ Western High Plains } \\
\hline \multicolumn{5}{|l|}{ Playa } \\
\hline Cropland & $27.8(1.8)$ & $18.4(0.2)$ & $375(68)$ & $9(2.3)$ \\
\hline Grassland & $28.6(2.5)$ & $18.3(0.2)$ & $298(96)$ & $12(1.4)$ \\
\hline CRP & $21.0(0.5)$ & $17.6(0.2)$ & $582(79)$ & $13(1.2)$ \\
\hline \multicolumn{5}{|l|}{ Upland } \\
\hline Cropland & $15.2(1.0)$ & $19.1(0.3)$ & $453(255)$ & $6(1.8)$ \\
\hline Grassland & $12.9(1.4)$ & $19.5(0.2)$ & $299(45)$ & $16(2.0)$ \\
\hline CRP & $11.7(1.2)$ & $20.2(1.6)$ & $724(214)$ & $11(1.1)$ \\
\hline
\end{tabular}




\subsection{Rainwater Basin Uplands}

There was no land use * year interaction for any GHG emissions in RWB uplands. There was seasonal variation in all GHG emissions with the bulk of emissions occurring during peak growing season. Emissions of $\mathrm{CO}_{2}$ and $\mathrm{CH}_{4}$ did not differ among land use types or by year. Emissions of $\mathrm{N}_{2} \mathrm{O}$ differed among land use type and by year. Cropland uplands emitted $648 \%$ more $\mathrm{N}_{2} \mathrm{O}$ than WRP and reference uplands (Table 1). In addition, twice as much $\mathrm{N}_{2} \mathrm{O}$ was emitted in 2013 than 2012. Overall, net $\mathrm{CO}_{2 \text {-equiv }}$ emissions did not differ among land use types or by year (Figure $1(\mathrm{~b})$ ).

There was no land use * year interaction for soil moisture or soil temperature in RWB uplands. Soil moisture differed among land use types and by year. Cropland uplands were 34\% more moist than WRP uplands; soil moisture in reference uplands did not differ from cropland or WRP uplands (Table 3). Similar to wetlands, RWB uplands were 14\% more moist in 2013 than 2012. Soil temperature differed among land use types with WRP uplands averaging $1.1^{\circ} \mathrm{C}$ warmer than cropland and reference uplands, which did not differ (Table 3). In 2012, soils averaged $1.6^{\circ} \mathrm{C}$ warmer than in 2013.

In 2013, plant species richness differed among land uses in adjacent uplands. As expected, upland croplands contained half as many plant species as reference condition and WRP uplands, which did not differ from one another. Aboveground biomass was similar among land uses (Table 3).

\subsection{Western High Plains Wetlands}

There was a land use type ${ }^{*}$ year interaction for playa $\mathrm{CO}_{2}$ emissions. Emissions of $\mathrm{CO}_{2}$ did not differ within land use types between years for cropland and grassland playas but in CRP playas it was 29\% lower in 2013 than 2012 (Table 1). Emissions of $\mathrm{CO}_{2}$ did not differ among landscape positions. Fluxes in $\mathrm{CH}_{4}$ differed by land use type ${ }^{\star}$ landscape position and land use type ${ }^{*}$ year interactions. Wetland center contributed most to $\mathrm{CH}_{4}$ emissions but only differed from wetland edge, except in CRP playas, where $\mathrm{CH}_{4}$ emissions were negligible throughout the wetland (Table 2). Wetland edge and $1 / 2$ distance between center and edge did not differ. There were no differences among land use types in 2012, however, in 2013, cropland and grassland playas emitted 46 and 23 times more $\mathrm{CH}_{4}$, respectively, than playas in CRP (Table 1). Only cropland playas differed between years, changing from a small sink for $\mathrm{CH}_{4}$ in 2012 to the greatest contributor of $\mathrm{CH}_{4}$ emissions among land uses in 2013. There were no interactions among fixed effects for playa $\mathrm{N}_{2} \mathrm{O}$ emissions. Emissions of $\mathrm{N}_{2} \mathrm{O}$ differed among land use types but not among landscape positions or by year. Playas in CRP emitted $43 \%$ less $\mathrm{N}_{2} \mathrm{O}$ than cropland playas; grassland playas did not differ from either cropland or CRP playas (Table 1). Net emissions did not differ among landscape positions but did have a land use ${ }^{\star}$ year interaction. There were no differences among land use types in 2012, however, in 2013, cropland and grassland playas emitted $75 \%$ and $39 \%$ more $\mathrm{CO}_{2 \text {-equiv, }}$ respectively, than playas in 
CRP (Table 1). Cropland and CRP playas differed among years. Cropland playa $\mathrm{CO}_{2 \text {-equiv }}$ emissions increased 64\% from 2012 to 2013 while emissions from playas in CRP decreased 28\% from 2012 to 2013 (Table 1; Figure 1(c)). Seasonal variation existed for all GHG emissions with the bulk of emissions occurring during peak growing season.

Soil moisture differed among landscape positions and had a land use ${ }^{*}$ year interaction. As expected, the wetland edge was $42 \%$ and $30 \%$ less moist than the wetland center and 1/2 distance between center and edge positions, respectively. In 2012, grassland playas had about $60 \%$ greater soil moisture than CRP and cropland playas. However, in 2013, cropland playas were $73 \%$ more moist than CRP playas; grassland playas did not differ from either cropland or CRP playas. Soil moisture in playas differed seasonally and generally declined throughout the season. Soil temperature was similar among landscape positions but had a land use * year interaction. In 2012, soil temperatures in cropland and grassland playas were $1.6^{\circ} \mathrm{C}$ warmer than CRP soils. There were no differences in soil temperature among land uses in 2013. Cropland and grassland playa soils were about $0.9^{\circ} \mathrm{C}$ warmer in 2012 than in 2013; soil temperatures in CRP playas did not differ between years. There was also seasonal variation in soil temperature which was highest during the summer.

Plant species richness did not differ among land uses in playas in 2013. Also, aboveground biomass did not differ among land use types in the model, however, land use type differences were evident in the Multiple Range Test. Playas in CRP had 64\% greater aboveground biomass than native grassland playas; aboveground biomass in cropland playas were also $23 \%$ greater than native grassland playas but did not differ significantly from either land use type (Table 3 ).

\subsection{Western High Plains Uplands}

There was no land use ${ }^{\star}$ year interaction for $\mathrm{CO}_{2}$ emissions in uplands. Emissions of $\mathrm{CO}_{2}$ did not differ among land use types or by year. There was a significant land use type ${ }^{*}$ year interaction for $\mathrm{CH}_{4}$ flux. There were no differences in $\mathrm{CH}_{4}$ flux among land use types in 2012. However, in 2013, grassland uplands were a significantly stronger sink for atmospheric $\mathrm{CH}_{4}$ than cropland or CRP uplands, which did not differ from one another (Table 1). Only grassland uplands differed between years having $\mathrm{CH}_{4}$ sink strength on average 10 times greater in 2013 than in 2012. There was no land use ${ }^{*}$ year interaction for $\mathrm{N}_{2} \mathrm{O}$ emissions in uplands. Upland $\mathrm{N}_{2} \mathrm{O}$ production did not differ among land use types or by year. There was also no land use ${ }^{\star}$ year interaction for net emissions in uplands. Net $\mathrm{CO}_{2 \text {-equiv }}$ emissions did not differ among land use type or by year (Figure 1(d)). Seasonal variation existed for all GHG emissions with the bulk occurring during peak growing season.

There was a land use type ${ }^{\star}$ year interaction for upland soil moisture. There were no land use type differences among uplands for either year but cropland uplands were $71 \%$ more moist in 2013 than in 2012; CRP and grassland uplands 
did not differ between years. There was no land use type * year interaction for upland soil temperature. There were no differences in upland soil temperature among land use types or between years (Table 3).

In 2013, plant species richness differed among land uses in adjacent uplands. On average, upland native grasslands contained nearly 3 times as many plant species as croplands; uplands in CRP did not differ significantly from native grasslands or croplands (Table 3). Although there was not statistical significance, aboveground biomass in CRP uplands was nearly twice as high as cropland and native grassland uplands (Table 3 ).

\section{Discussion}

\subsection{Emissions in Rainwater Basin Playas/Uplands}

Ecosystem restoration has been recognized in international climate policy frameworks as a possible mechanism to mitigate climate change [48]. Conservation programs and practices are widely implemented throughout the High Plains of the U.S., and with an understanding of their influence on GHG flux in the region, better-informed conservation strategies can be utilized with consideration to climate mitigation. The focus of this study was on GHG emissions from playas and watersheds, which compliments earlier studies of carbon storage dynamics throughout playas and watersheds in the High Plains [49] [50].

In playas and their watersheds, $\mathrm{CO}_{2}$ was the greatest contributor to net emissions and because opaque collection chambers were used, samples included aboveground plant respiration as well as soil respiration. Increased deposits of upland soils and higher nutrient loads from upland runoff encourage establishment of productive, monotypic stands of vegetation that outcompete many native wetland plant species [51]. Inherently invasive plants such as Typha angustifolia (Narrowleaf Cattail) and Scirpus fluviatilis (River Bulrush) flourish under higher nutrient concentrations and produce a substantial amount of root exudates which can be an important contribution to soil C [52] and consequently higher $\mathrm{CO}_{2}$ output. [53] documented changes in plant community composition in playas in the RWB upon restoration of former cropland and found that playas in active cropland were associated with three species of management concern; $T$. angustifolia, S. fluviatilis, and Phalaris arundinacea (Reed Canarygrass). The high productivity of these invasive species is likely an important factor in the higher overall $\mathrm{CO}_{2}$ emissions from cropland playas.

Methane emissions were variable within and among playas which may be due, in part, to random ebullition events in saturated soils beneath collection chambers [54]. Emergent vegetation within chambers may also provide a route for $\mathrm{CH}_{4}$ transport into the atmosphere. Transport of $\mathrm{CH}_{4}$ through plant tissues has been documented in multiple studies [55] [56] [57] and is considered an important component in $\mathrm{C}$ cycling between wetlands and the atmosphere [58]. However, emergent vegetation may also provide an aerobic rhizosphere near the soil surface and $\mathrm{CH}_{4}$ produced in deeper soil layers may be converted back into $\mathrm{CO}_{2}$ 
by methanotrophs [59]. Although they were not statistically different, playas restored through the WRP emitted half as much $\mathrm{CH}_{4}$, on average (error bars did not overlap), than reference condition or cropland playas which contributed to WRP having the lowest net $\mathrm{C}$ emissions.

Playas in WRP were drier and warmer than playas in other land uses which may be a factor in their lower overall net $\mathrm{C}$ emissions. Indeed, some reference condition and cropland playas received water from non-natural sources including, wetland irrigation runoff, whereas no WRP playas received supplemental water. Warmer soil temperatures in WRP playas could also be due to lower plant cover which could have increased surface evaporation rates, consequently lowering soil moisture. Sediment removal from playa basins in WRP may also result in topsoils with a lower water holding capacity due to compaction from heavy equipment and removal of lower bulk density soil organic matter overlying the high density clay pan (Bt layer) beneath playas [50].

Soil $\mathrm{N}_{2} \mathrm{O}$ emissions are regulated by microbial nitrification/denitrification processes and in wetlands such as playas with erratic hydroperiods, $\mathrm{N}_{2} \mathrm{O}$ emissions can be higher because wetland soils are not typically completely anoxic [21] [60]. Playas restored through the WRP had similar $\mathrm{N}_{2} \mathrm{O}$ emissions compared to cropland and reference condition playas, suggesting playa restoration may not increase $\mathrm{N}_{2} \mathrm{O}$ emissions. Lower aboveground plant detrital inputs due to vegetation management practices such as discing, grazing, burning, and herbicide application may limit $\mathrm{N}_{2} \mathrm{O}$ emissions in WRP playas by limiting the amount of available $\mathrm{NO}_{3}$ for denitrification. Removing sediments as a restoration practice in WRP playas can also remove excess $\mathrm{N}$ from the basin that would otherwise be available for denitrification. Indeed, [50] found that playas restored through sediment removal practices had lower soil $\mathrm{N}$ levels in the top $5 \mathrm{~cm}$ than reference condition and cropland playas.

Because there are likely lower levels of microbially available $\mathrm{N}$ in WRP playa soils due to sediment removal, the similarity in playa $\mathrm{N}_{2} \mathrm{O}$ emissions among land uses may indicate changes in microbial community structure and biogeochemical functioning in WRP playas. Other studies have found land use changes and restoration activities may alter microbial communities [61] [62]. [63] found that $\mathrm{N}_{2} \mathrm{O}$ emissions increased with plant species richness in wetland microcosms and plant diversity is often considered to be an important factor in soil microbial diversity [64] [65]. Although plant species richness did not differ among land use types in this study, [53] found that plant species richness in WRP playas was higher when sediment had been removed from basins.

Agricultural soil management activities such as fertilizer application and other cropping practices contribute $69 \%$ to U.S. $\mathrm{N}_{2} \mathrm{O}$ emissions [17]. Croplands in the RWB receive fertilizer amendments to increase crop yields and in our study, all cropland uplands were irrigated. Excess soil $\mathrm{N}$ and moist soil conditions in cropland uplands made them the highest contributor to $\mathrm{N}_{2} \mathrm{O}$ emissions, producing on average $648 \%$ more $\mathrm{N}_{2} \mathrm{O}$ than reference condition and WRP uplands and about $450 \%$ more than playas. 


\subsection{Emissions in Western High Plains Playas/Uplands}

Playas embedded in CRP in the WHP have 18\% higher levels of C in the top 50 $\mathrm{cm}$ of soil than playas in cropland [49]. In our study, playas and uplands in CRP had higher aboveground biomass than playas and uplands in other land uses. However, $\mathrm{CO}_{2}$ emissions from playas and uplands did not differ among land uses, likely due to microbial respiration being limited by soil moisture, especially in 2012. [54] found that microbial activity was inhibited when soil moisture fell below 20\% VWC. On average, soil moisture in 2012 was 23\% VWC in playas and $11 \%$ VWC in adjacent uplands. In 2013, rainfall totals were similar to historic averages and likely a major contributor to higher $\mathrm{CH}_{4}$ and $\mathrm{N}_{2} \mathrm{O}$ emissions in cropland and native grassland playas. Due to dense, exotic vegetation associated with CRP, playas embedded in CRP receive less water runoff and are inundated less frequently than playas in other land uses [26], leading them to be smaller contributors to $\mathrm{CH}_{4}$ emissions in 2013. Emissions of $\mathrm{N}_{2} \mathrm{O}$ were also lower in CRP playas due to less frequent flooding, however, $\mathrm{N}_{2} \mathrm{O}$ did not differ among land uses in uplands as they did in the RWB. In this study, only one cropland site was influenced by irrigation in the WHP; in the RWB all cropland sites were irrigated.

Native grassland uplands were the greatest atmospheric sink for $\mathrm{CH}_{4}$ which is consistent with other studies highlighting the importance of grassland ecosystems in $\mathrm{CH}_{4}$ oxidation [66] [67]. [68] found that microbial oxidation of $\mathrm{CH}_{4}$ tended to be slightly higher with higher plant species diversity. Upland native grasslands had higher plant species richness than croplands which may promote $\mathrm{CH}_{4}$ oxidation in native grassland soils in the WHP.

\subsection{Regional Differences}

Our study builds on previous investigations on GHG fluxes from cropland and restored wetlands in the Prairie Pothole Region, PPR [38] [39] [40]. Within the Wetland Continuum Concept, ecological processes including those associated with GHG emissions, are driven by hydrogeomorphology and climate [69]. Because wetlands evaluated in [38] are likely similar to playas in basin morphology and water budget, differences in GHG emissions among these Great Plains regions may be primarily due to climate. Emissions of $\mathrm{CO}_{2}, \mathrm{CH}_{4}$, and $\mathrm{N}_{2} \mathrm{O}$ were higher, on average, in RWB playas compared to PPR wetlands. It is likely that higher daily soil temperatures and extended growing seasons contributed to net emissions in RWB playas which were $34 \%$ higher than in PPR wetlands. However, wetlands in comparatively lower latitudes than the PPR, such as the RWB, also have higher evapotranspiration rates and regions receiving less annual rainfall such as the WHP, warmer soils may not lead to higher GHG emissions due to soil moisture restrictions. Emissions from WHP playas were about $33 \%$ and $50 \%$ lower than PPR and RWB wetlands, respectively. Other localized factors including soils, floral/faunal composition, and management practices could also have contributed to regional differences in emissions. 


\subsection{Conservation Implications}

Although wetlands continue to be degraded and an estimated 50\% of all wetlands have been lost worldwide, the services afforded by these ecosystems are highly valued [70]. Wetland restoration efforts and "no net loss" policy goals are in place to prevent further wetland loss and restore ecosystem services in the U.S. However, in some cases, such efforts may have a negative influence on climate [6] [16].

In the RWB, wetland restorations through the WRP have restored about 2600 ha of wetlands and uplands in a region that has lost $90 \%$ of its historic wetland area [36] [71]. A primary goal for wetland restoration in the RWB is to provide adequate forage habitat for migrating waterfowl [72]. Managing vegetation in playas in WRP to prevent dense perennials such as T. angustifolia, S. fluviatilis, and $P$. arundinacea through discing, grazing, burning, and herbicide application likely limits the spread of these invasives resulting in lower aboveground plant biomass and a higher diversity of plant species [53]. Restoration practices such as sediment removal can also change plant species composition as well as lower excess nutrients in playas [53] [73]. Practices associated with WRP in the RWB effectively reduce GHG emissions from playas, thus climate mitigation is an ecosystem service that may be enhanced through playa restoration in the RWB.

Due to its extent in the High Plains, CRP has a greater influence on playas than any other conservation program [19]. Playas embedded in CRP produced less net $\mathrm{CO}_{2 \text {-equiv }}$ emissions than native grassland and cropland playas. Because they are inundated less frequently as a result of exotic grasses in the upland, however, their capacity to provide other services such as wildlife habitat and aquifer recharge may be reduced [19]. The benefits of lower gas emissions must be appropriately weighted against loss of services related to shorter hydroperiods in playas in CRP. Furthermore, native grassland watersheds in the WHP should be maintained in order to maximize atmospheric $\mathrm{CH}_{4}$ oxidation and climate mitigation services.

\section{Acknowledgements}

We thank Randy Stutheit of Nebraska Games and Parks Commission who assisted in locating study playas and landowner information. We also thank the U.S. Fish and Wildlife Service for providing accommodations during field stay. Thanks to Alex Sazama and Raju Katwal for assisting with data collection. We also thank private landowners that allowed us access to their playas. This research was funded by the EPA through the 2011 Wetland Program Development Grant Program: Project CD-97731401. Funding for this project was also provided by the U.S. Geological Survey Climate and Land Use Change R \& D Program. This research was also partially supported through the Natural Resource Conservation Service-CEAP Wetlands Program. Any use of trade, firm, or product names is for descriptive purposes only and does not imply endorsement by the U.S. Government. 


\section{Conflicts of Interest}

The authors declare no conflicts of interest regarding the publication of this paper.

\section{References}

[1] Pielke, R.A., Marland, G., Betts, R.A., Chase, T.N., Eastman, J.L., Niles, J.O., Niyogi, D.D.S. and Running, S.W. (2002) The Influence of Landuse Change and Landscape Dynamics on the Climate System: Relevance to Climate-Change Policy beyond the Radiative Effect of Greenhouse Gases. Philosophical Transactions of the Royal Society of London, Series A, 360, 1705-1719.

[2] Houghton, R.A. (1990) The Global Effects of Tropical Deforestation. Environmental Science \& Technology, 24, 414-422. https://doi.org/10.1021/es00074a001

[3] Schulze, E.D. (2006) Biological Control of the Terrestrial Carbon Sink. Biogeosciences, 3, 147-166. https://doi.org/10.5194/bg-3-147-2006

[4] Schlesinger, W.H. and Andrews, J.A. (2000) Soil Respiration and the Global Carbon cycle. Biogeochemistry, 48, 7-20. https://doi.org/10.1023/A:1006247623877

[5] Syswerda, S.P., Corbin, A.T., Mokma, D., Kravchenko, A.N. and Robertson, G.P. (2011) Agricultural Management and Soil Carbon Storage in Surface vs. Deep Layers. Soil Science Society of America Journal, 75, 92-101. https://doi.org/10.2136/sssaj2009.0414

[6] Bridgham, S.D., Megonigal, J.P., Keller, J.K., Bliss, N.B. and Trettin, C. (2006) The Carbon Balance of North American Wetlands. Wetlands, 26, 889-916. https://doi.org/10.1672/0277-5212(2006)26[889:TCBONA]2.0.CO;2

[7] Cronk, J.K. and Fennessy, M.S. (2001) Wetland Plants: Biology and Ecology. CRC Press/Lewis Publishers, Boca Raton, FL, 440 p. https://doi.org/10.1201/9781420032925

[8] IPCC (2007) In: Solomon, S., Qin, D., Manning, M., Chen, Z., Marquis, M., Averyt, K.B., Tignor, M. and Miller, H.L., Eds., Climate Change 2007: The Physical Science Basis. Contribution of Working Group I to the Fourth Assessment Report of the Intergovernmental Panel on Climate Change, Cambridge University Press, Cambridge, UK and New York, USA, 996 p.

[9] Wooten, H.H. and Jones, L.A. (1955) The History of Our Drainage Enterprises. In: The Yearbook of Agriculture, 1955, U.S. Department of Agriculture, Washington DC, 84th Congress, 1st Session, House Document No. 32, 478-498.

[10] Dahl, T.E. and Johnson, C.E. (1991) Wetlands-Status and Trends in the Conterminous United States, Mid-1970's to Mid-1980's: Washington, D.C., U.S. Fish and Wildlife Service, $22 \mathrm{p}$.

[11] Armentano, T.V. and Menges, E.S. (1986) Patterns of Change in the Carbon Balance of Organic Soil-Wetlands of the Temperate Zone. Journal of Ecology, 74, 755-774. https://doi.org/10.2307/2260396

[12] Maltby, E. and Immirzi, P. (1993) Carbon Dynamics in Peatlands and Other Wetland Soils, Regional and Global Perspectives. Chemosphere, 27, 999-1023. https://doi.org/10.1016/0045-6535(93)90065-D

[13] Euliss Jr., N.H., Gleason, R.A., Olness, A., McDougal, R.L., Murkin, H.R., Robarts, R.D., Bourbonniere, R.A. and Warner, B.G. (2006) North American Prairie Wetlands Are Important Nonforested Land-Based Carbon Storage Sites. Science of the Total Environment, 361, 179-188. https://doi.org/10.1016/j.scitotenv.2005.06.007 
[14] Smith, L.M., Euliss Jr., N.H., Wilcox, D. and Brinson, M. (2008) Application of a Geomorphic and Temporal Perspective to Wetland Management in North America. Wetlands, 28, 563-577. https://doi.org/10.1672/07-155.1

[15] Whiting, G.J. and Chanton, J.P. (2001) Greenhouse Carbon Balance of Wetlands: Methane Emission versus Carbon Sequestration. Tellus Series B Chemical and Physical Meteorology, 53, 521-528.

[16] Thornton, F.C. and Valente, R.J. (1996) Soil Emissions of Nitrous Oxide from No-Till Corn. Soil Science Society of America Journal, 60, 1127-1133. https://doi.org/10.2136/sssaj1996.03615995006000040024x

[17] Environmental Protection Agency, EPA (2012) Inventory of U.S. Greenhouse Gas Emissions and Sinks.

https://www.epa.gov/ghgemissions/inventory-us-greenhouse-gas-emissions-and-sin ks-1990-2012

[18] Zhu, Z., Bouchard, M., Butman, D., Hawbaker, T., Li, Z., Liu, J., Liu, S., McDonald, C., Reker, R., Sayler, K., Sleeter, B., Sohl, T., Stackpoole, S., Wein, A. and Zhu, Z. (2011) Baseline and Projected Future Carbon Storage and Greenhouse-Gas Fluxes in the Great Plains Region of the United States. U.S. Geological Survey Professional Paper 1787, 28.

[19] Smith, L.M., Haukos, D.A., McMurry, S.T., LaGrange, T. and Willis, D. (2011) Ecosystem Services Provided by Playas in the High Plains: Potential Influences of USDA Conservation Programs. Ecological Applications, 21, S82-S92. https://doi.org/10.1890/09-1133.1

[20] Dahl, T.E. (2000) Status and Trends of Wetlands in the Conterminous United States 1986-1997. U.S. Fish and Wildlife Service, Washington DC.

[21] Smith, L.M. (2003) Playas of the Great Plains. University of Texas Press, Austin.

[22] Johnson, L.A., Haukos, D.A., Smith, L.M. and McMurry, S.T. (2012) Physical Loss and Modification of Southern Great Plains Playas. Journal of Environmental Management, 112, 275-283. https://doi.org/10.1016/j.jenvman.2012.07.014

[23] Luo, H.R., Smith, L.M., Allen, B.L. and Haukos, D.A. (1997) Effects of Sedimentation on Playa Wetland Volume. Ecological Applications, 7, 247-252.

[24] Tsai, J.S., Venne, L.S., McMurry, S.T. and Smith, L.M. (2007) Influences of Land Use and Wetland Characteristics on Water Loss Rates and Hydroperiods of Playas in the Southern High Plains, USA. Wetlands, 27, 683-692.

[25] Smith, L.M. and Haukos, D.A. (2002) Floral Diversity in Relation to Playa Wetland Area and Watershed Disturbance. Conservation Biology, 16, 964-974. https://doi.org/10.1046/j.1523-1739.2002.00561.x

[26] Cariveau, A., Pavlacky, D., Bishop, A. and LaGrange, T. (2011) Effects of Surrounding Land Use on Playa Inundation Following Intense Rainfall. Wetlands, 31, 65-73. https://doi.org/10.1007/s13157-010-0129-4

[27] McCarl, B.A. and Schneider, U.A. (2001) Greenhouse Gas Mitigation in U.S. Agriculture and Forestry. Science, 294, 2481 -2482. https://doi.org/10.1126/science.1064193

[28] Haukos, D.A. and Smith, L.M. (1994) The Importance of Playa Wetlands to Biodiversity of the Southern High Plains. Landscape and Urban Planning, 28, 83-98. https://doi.org/10.1016/0169-2046(94)90046-9

[29] LaGrange, T.G. (2005) A Guide to Nebraska's Wetlands and Their Conservation Needs. 2nd Edition, Nebraska Games and Parks Commission, Lincoln, Nebraska, USA. 
[30] U.S. Department of Agriculture (2009) 2007 Census of Agriculture. Vol. 1. U.S. Summary and State Reports. Geographic Area Series. Part 51. USDA, National Agricultural Statistics Service, Washington DC.

[31] Daniel, D.W., Smith, L.M., Haukos, D.A., Johnson, L.A. and McMurry, S.T. (2014) Land Use and Conservation Reserve Program Effects on the Persistence of Playa Wetlands in the High Plains. Environmental Science \& Technology, 48, 4282-4288. https://doi.org/10.1021/es404883s

[32] Stutheit, R.G., Gilbert, M.C., Whited, P.M. and Lawrence, K.L. (2004) A Regional Guidebook for Applying the Hydrogeomorphic Approach to Assessing Wetland Functions of Rainwater Basin Depressional Wetlands in Nebraska. U.S Army Corp of Engineers, Washington DC.

[33] Nation Climatic Data Center (2012) Online Data Service. https://www.ncdc.noaa.gov/data-access

[34] U.S. Department of Agriculture, Soil Conservation Service (1981) Soil Survey of Clay County, Nebraska. University of Nebraska, Conservation and Survey Division.

[35] Kuzila, M.S. (1984) Genesis and Morphology of Soils in and Around Large Depressions in Clay County, Nebraska. PhD Dissertation, University of Nebraska, Lincoln.

[36] Gersib, R.A. (1991) Nebraska Wetlands Priority Plan. Nebraska Game and Parks Commission.

[37] Livingston, G.P. and Hutchinson, G.L. (1995) Enclosure-Based Measurement of Trace Gas Exchange: Applications and Sources of Error. In: Matson, P.A. and Harriss, R.C., Eds., Biogenic Trace Gases. Measuring Emissions from Soil and Water, Blackwell Science, Inc., Cambridge, MA, 14-51.

[38] Gleason, R.A., Tangen, B.A., Browne, B.A. and Euliss Jr., N.H. (2009) Greenhouse Gas Flux from Cropland and Restored Wetlands in the Prairie Pothole Region. Soil Biology and Biochemistry, 41, 2501-2507. https://doi.org/10.1016/j.soilbio.2009.09.008

[39] Finocchiaro, R.G., Tangen, B.A. and Gleason, R.A. (2014) Greenhouse Gas Fluxes of Grazed and Hayed Wetland Catchments in the U.S. Prairie Pothole Ecoregion. Wetland Ecology \& Management, 22, 305-324. https://doi.org/10.1007/s11273-013-9331-5

[40] Tangen, B.A., Finocchiaro, R.G. and Gleason, R.A. (2015) Effects of Land Use on Greenhouse Gas Fluxes and Soil Properties of Wetland Catchments in the Prairie Pothole Region of North America. Science of the Total Environment, 533, 391-409. https://doi.org/10.1016/j.scitotenv.2015.06.148

[41] Lotfield, N., Flessa, H., Augustin, J. and Beese, F. (1997) Automated Gas Chromatographic System for Rapid Analysis of the Atmospheric Trace Gases Methane, Carbon Dioxide, and Nitrous Oxide. Journal of Environmental Quality, 26, 560-564. https://doi.org/10.2134/jeq1997.00472425002600020030x

[42] Parkin, T., Mosier, A.R., Smith, J., Venterea, R., Johnson, J., Reicosky, D., Doyle, G., McCarty, G. and Baker, J. (2003) Chamber-Based Trace Gas Flux Measurement Protocol. USDA-ARS GRACEnet, 1-28.

[43] IPCC (2001) Climate Change 2001: The Scientific Basis. Cambridge University Press, Cambridge, UK; New York, USA.

[44] Reddy, K.R. and Delaune, R.D. (2008) Biogeochemistry of Wetlands: Science and Applications. CRC Press, Boca Raton, FL, 774. https://doi.org/10.1201/9780203491454

[45] Inglett, K.S., Inglett, P.W., Reddy, K.R. and Osborne, T.Z. (2012) Temperature Sen- 
sitivity of Greenhouse Gas Production in Wetland Soils of Different Vegetation. Biogeochemistry, 108, 77-90. https://doi.org/10.1007/s10533-011-9573-3

[46] Evans, R.A. and Love, R.M. (1957) The Step-Point Method of Sampling: A Practical Tool in Range Research. Journal of Range Management Archives, 10, 208-212. https://doi.org/10.2307/3894015

[47] Bonham, C.D. (1989) Measurements of Terrestrial Vegetation. John Wiley \& Sons, New York, 33-39.

[48] Society for Ecological Restoration International (2007) Ecological Restoration: A Global Strategy for Mitigating Climate Change. ScienceDaily, 21 August 2007.

[49] O’Connell, J.L., Daniel, D.W., McMurry, S.T. and Smith, L.M. (2016) Soil Organic Carbon in Playas and Adjacent Prairies, Cropland, and CRP Land of the High Plains, USA. Soil and Tillage Research, 156, 16-24. https://doi.org/10.1016/j.still.2015.09.012

[50] Daniel, D.W., Smith, L.M. and McMurry, S.T. (2017) Effects of Sediment Removal and Surrounding Land Use on Carbon and Nitrogen Storage in Playas and Watersheds in the Rainwater Basin Region of Nebraska. Soil and Tillage Research, 174, 169-176. https://doi.org/10.1016/j.still.2017.07.001

[51] LaGrange, T.G., Stutheit, R., Gilbert, M. and Shurtliff, D. (2011) Sedimentation of Nebraska's Playa Wetlands: A Review of Current Knowledge and Issues. Nebraska Game and Parks Commission, Lincoln, 62 p.

[52] Bardgett, R.D., Bowman, W.D., Kaufmann, R. and Schmidt, S.K. (2005) A Temporal Approach to Linking Aboveground and Belowground Ecology. Trends in Ecology and Evolution, 20, 634-641. https://doi.org/10.1016/j.tree.2005.08.005

[53] Beas, B.J., Smith, L.M., LaGrange, T.G. and Stutheit, R. (2013) Effects of Sediment Removal on Vegetation Communities in Rainwater Basin Playa Wetlands. Journal of Environmental Management, 128, 371-379. https://doi.org/10.1016/j.jenvman.2013.04.063

[54] Smith, K.A., Ball, T. and Conen, F. (2003) Exchange of Greenhouse Gases between Soil and Atmosphere: Interactions of Soil Physical Factors and Biological Processes. European Journal of Soil Science, 54, 779-791. https://doi.org/10.1046/j.1351-0754.2003.0567.x

[55] Whiting, G.J. and Chanton, J.P. (1992) Plant-Dependent CH4 Emission in a Subarctic Canadian Fen. Global Biogeochemical Cycles, 6, 225-231. https://doi.org/10.1029/92GB00710

[56] Shannon, R.D., White, J.R., Lawson, J.E. and Gilmour, B.S. (1996) Methane Efflux from Emergent Vegetation in Peatlands. Journal of Ecology, 84, 239-246. https://doi.org/10.2307/2261359

[57] Joabsson, A., Christensen, T.R. and Wallen, B. (1999) Vascular Plant Controls on Methane Emissions from Northern Peatforming Wetlands. Trends in Ecology \& Evolution, 14, 385-388. https://doi.org/10.1016/S0169-5347(99)01649-3

[58] Sebacher, D.I., Harriss, R.C. and Bartlett, K.B. (1985) Methane Emissions to the Atmosphere through Aquatic Plants. Journal of Environmental Quality, 14, 40-46. https://doi.org/10.2134/jeq1985.00472425001400010008x

[59] Gilbert, B. and Frenzel, P. (1995) Methanotrophic Bacteria in the Rhizosphere of Rice Microcosms and Their Effect on Porewater Methane Concentration and Methane Emission. Biology and Fertility of Soils, 20, 93-100. https://doi.org/10.1007/BF00336586

[60] Myrold, D.D. (1999) Transformations of Nitrogen. In: Sylvia, D.M., Fuhrmann, J.J., 
Hartel, P.G. and Zuberer, D.A., Eds., Principles and Applications of Soil Microbiology, Prentice Hall, Upper Saddle River, NJ.

[61] D’Angelo, E.M., Karathanasis, A.D., Sparks, E.J., Ritchey, S.A. and Wehr-McChesney, S.A. (2005) Soil Carbon and Microbial Communities at Mitigated and Late Successional Bottomland Forest Wetlands. Wetlands, 25, 162-175.

[62] Hartman, W.H., Richardson, C.J., Vilgalys, R. and Bruland, G.L. (2008) Environmental and Anthropogenic Controls over Bacterial Communities in Wetland Soils. Proceedings of the National Academy of Sciences of the United States of America, 105, 17842-17847. https://doi.org/10.1073/pnas.0808254105

[63] Chang, J., Fan, X., Sun, H., Zhang, C., Song, C., Chang, S.X. and Ge, Y. (2014) Plant Species Richness Enhances Nitrous Oxide Emissions in Microcosms of Constructed Wetlands. Ecological Engineering, 64, 108-115. https://doi.org/10.1016/j.ecoleng.2013.12.046

[64] Rovira, A.D. (1965) Interactions between Plant Roots and Soil Micro-Organisms. Annual Review in Microbiology, 19, 241-266.

https://doi.org/10.1146/annurev.mi.19.100165.001325

[65] Bolton, H., Fredrickson, J.K. and Elliot, L.F. (1993) Microbial Ecology of the Rhizosphere. Microbial Production of Plant Growth Regulators. In: Metting Jr., F.B., Ed., Soil Microbial Ecology. Applications in Agricultural and Environmental Management, Marcel Dekker, Inc., New York, 27-63.

[66] Willison, T.W., Webster, C.P., Goulding, K.W.T. and Powlson, D.S. (1995) Methane Oxidation in Temperate Soils Effects of Land Use and the Chemical Form of Nitrogen-Fertilizer. Chemosphere, 30, 539-546. https://doi.org/10.1016/0045-6535(94)00416-R

[67] Le Mer, J. and Roger, P. (2001) Production, Oxidation, Emission and Consumption of Methane by Soils: A Review. European Journal of Soil Biology, 37, 25-50. https://doi.org/10.1016/S1164-5563(01)01067-6

[68] Niklaus, P.A., Wardle, D.A. and Tate, K.R. (2006) Effects of Plant Species Diversity and Composition on Nitrogen Cycling and the Trace Gas Balance of Soils. Plant and Soil, 282, 83-98. https://doi.org/10.1007/s11104-005-5230-8

[69] Euliss Jr., N.H., Labaugh, W., Fredrickson, L.H., Mushet, D.M., Laubhan, M.R.K., Swanson, G.A., Winter, T.C., Rosenberry, D.O. and Nelson, R.D. (2004) The Wetland Continuum: A Conceptual Framework for Interpreting Biological Studies. Wetlands, 24, 448-458.

[70] Woodward, R.T. and Wui, Y.S. (2001) The Economic Value of Wetland Services: A Meta-Analysis. Ecological Economics, 37, 257-270. https://doi.org/10.1016/S0921-8009(00)00276-7

[71] Bishop, A.A. and Vrtiska, M. (2008) Effects of the Wetlands Reserve Program on Waterfowl Carrying Capacity in the Rainwater Basin Region of South-Central Nebraska. US Fish and Wildlife Service, Grand Island, Nebraska, USA.

[72] Rainwater Basin Joint Venture. Best Management Practices for Rainwater Basin Wetlands.

http://efotg.sc.egov.usda.gov/references/public/NE/rainwaterbasinwetlandsmanage ment.pdf

[73] Daniel, D.W. (2015) Greenhouse Gas Fluxes and Carbon Storage Dynamics in Playa Wetlands: Restoration Potential to Mitigate Climate Change. Dissertation, Oklahoma State University, Stillwater, OK. 